\title{
BINGKAI BERITA KUNJUNGAN KERJA KOMISI A DPRD JATIM KE BELANDA TERKAIT HARI JADI JATIM DALAM LEMBAGA PENYIARAN PUBLIK (LPP) TVRI JATIM DAN LEMBAGA PENYIARAN SWASTA (LPS) LOKAL JTV SURABAYA
}

\author{
Melissa $^{1}$; Ido Prijana Hadi; Nanang Krisdinanto \\ Jurusan Ilmu Komunikasi, Fakultas Ilmu Komunikasi \\ Universitas Kristen Petra \\ Jalan Siwalankerto 121-131 Surabaya, 60236 \\ Email: ido@petra.ac.id
}

\begin{abstract}
Media construct and make sense of the reality it serves to its audiences. Reality-construction and sense-making are influenced by internal (reporters, media organization) and external factors (sources, advertisers, others). Thus, news is a product of constructed reality. News is not something that is already out-there for the media to present to its audiences. Media chooses, selects, put emphasis on some details and facts, while (purposedly) overlooks others. The selection and emphasise are called framing. Framing enables the complex, disorganized realities, to be changed into organized, simple, and sensible realities. In this research, the news the A-Committee's excursion to Netherlands in relation to East Java's centenary in Public Service Broadcasting TVRI Jatim and Commercial (Private) Broadcast JTV are explored. Since the research intends to see how the media presents, exnominates, and puts emphasis on facts and details to make sense of the reality, this research uses Zhongdang Pan and Gerald $M$. Kosicki's framing analysis method. Hence, it was found, TVRI frames reality from the government's point of view, while JTV frames the reality from the watchdog role's point of view. The differences lays in historical, legal, and influences on media content. Thus, it was found that either public or commercial broadcasts television produce news according to their bias and interests that are seen through their newsframes.
\end{abstract}

Keywords: Constructivism, news frame, media content, Public Service Broadcasting TVRI Jawa Timur, Commercial (Private) Broadcasts JTV, Zhongdan Pan and Gerald M. Kosicki’s framing analysis

\section{PENDAHULUAN}

Pertengahan tahun 2007, media massa di Jawa Timur ramai memberitakan kunjungan kerja (kunker) anggota Dewan Perwakilan Rakyat Daerah dari Komisi Hukum dan Pemerintahan (A) DPRD Jawa Timur ke Belanda terkait keperluan pencarian data hari jadi Jatim. Kunjungan kerja tersebut mendapat sorotan masyarakat dan media karena dinilai sebagai dalih dewan untuk dapat berwisata ke Belanda menggunakan Anggaran Pendapatan dan Belanja Daerah (APBD). Tidak

${ }^{1}$ Melissa,. Alumni Jurusan Ilmu Komunikasi, UK Petra 
sedikit media yang terang-terangan memprotes kunjungan kerja tersebut, mulai dari media cetak, media elektronik maupun media online.

Harian Kompas edisi 7 Juli 2007 secara halus menyidir 'kunker' dengan memuat berita berjudul "Kunker DPRD Dituding Akal-Akalan". Di bagian bawah judul Kompas mencetak pernyataan anggota dewan Suli Da'im: "Tak Benar KBRI di Belanda Tidak Tahu". Tak kalah pedas pada hari yang sama, Metro TV mengeluarkan berita online berjudul "Anggota DPRD Jatim Diam-Diam Berangkat ke Luar Negeri". Teras berita Metro TV menggemakan pepatah kuno: "Anjing menggonggong kafilah berlalu" untuk menyamakan anggota dewan dengan kafilah yang mengacuhkan 'gonggongan' pihak-pihak pemrotes. Seakan turut meramaikan hujan protes, harian Surya (07/07/2007) memuat berita "Komisi A Berangkat Kunker ke Belanda" dengan lead berbau sindiran, dengan menulis:

"Batasan maksimal lima anggota DPRD yang boleh pergi ke luar negeri, tidak berlaku bagi Komisi A (Komisi Pemerintahan) DPRD Jatim. Rombongan komisi itu, 10 orang, kunjungan kerja (kunker) ke Belanda, Jumat (6/7).”

Kunjungan kerja Komisi A DPRD Jatim tersebut dipermasalahkan, karena dianggap melanggar aturan, menghabiskan anggaran, dan tidak penting atau urgent untuk dilakukan. Kunjungan kerja Komisi A dianggap menyalahi ketentuan Peraturan Menteri Dalam Negeri (Permendagri) nomor 20 tahun 2005 tentang Pedoman Perjalanan Dinas Luar Negeri bagi Pejabat/Pegawai di Lingkungan Departemen Dalam Negeri, Pemerintah Daerah dan Pimpinan serta Anggota Dewan Perwakilan Rakyat Daerah. Dalam peraturan itu disebutkan, rombongan kunjungan kerja dibatasi paling banyak lima orang, termasuk pimpinan rombongan (pasal 9). Pada nyatanya, jumlah anggota Komisi A yang berangkat kunker sebanyak sembilan orang. Kelebihan jumlah anggota tersebut, selain dinilai sebagai pelanggaran peraturan, juga dinilai sebagai tindak korupsi.

Penggunaan anggaran tersebut, dirinci oleh Jawa Pos edisi 08 Juli 2007 sebagai berikut: "total alokasi dana APBD Rp. 20 miliar. Dana kunker ke luar negeri sebesar Rp. 5 miliar. Alokasi untuk kunker Komisi A ke Belanda sendiri sejumlah Rp. 0,5 miliar dengan rincian tiap anggota mendapat jatah Rp. 50 juta dan uang saku berkisar antara Rp. 5-10 juta" (DASK APBD 2007 dalam Jawa Pos 08 Juli 2007). Jika ada sembilan anggota yang berangkat, berarti dana yang seharusnya disimpan adalah 4 x (Rp. 60 juta, dengan asumsi uang saku rata-rata Rp.10 juta) = Rp. 240 juta. Dana tersebut dianggap ironis oleh beberapa pihak karena pada tahun tersebut masih ada 37, 17 juta penduduk miskin Indonesia (data BPS 2007 dalam Simanjuntak, 2007) Terlebih lagi, kepergian Komisi A DPRD Jatim ke Belanda untuk mencari data hari jadi propinsi Jatim dianggap tidak perlu dilakukan. Data-data yang telah diketemukan dianggap cukup bagi penentuan hari jadi Jatim.

Teks berita adalah hasil konstruksi (Eriyanto, 2002). Dalam pandangan konstruktivisme, berita adalah hasil dari pemaknaan wartawan dan media terhadap realitas. Karena itu, peristiwa yang sama dapat dimaknai berbeda oleh wartawan atau media yang berbeda. Perbedaan ini juga dipengaruhi antara lain oleh tingkat ideologis, kekuatan ekstramedia, struktur organisasi, rutinitas media, dan individu (Shoemaker dan Reese, 1996:64). Perbedaan-perbedaan cara menyajikan berita tampak dari bagaimana media mengemas atau membingkai berita. Dalam konteks penelitian ini kunjungan kerja Komisi A DPRD Jatim ke Belanda menjadi fokus dengan melihat pembingkaian yang dilakukan dua media televisi yaitu TVRI Jawa Timur dan televisi lokal JTV Surabaya. 
Peneliti tertarik meneliti TVRI Jawa Timur karena: Pertama, dari segi historis, TVRI masa Orde Baru merupakan alat propaganda ${ }^{2}$ pemerintah. Hal ini ditegaskan Direktur Utama (Dirut) Perusahaan Jawatan (Perjan) TVRI Chairul Zen pada Agustus 2000 bahwa TVRI mengalami 'penjajahan' oleh pemerintah sehingga tidak berdaya. Peran TVRI sebagai alat propaganda pemerintah dibuktikan beberapa studi yang meneliti isi pemberitaan TVRI. Mereka mendapati, berita TVRI didominasi kegiatan seremonial dan pembangunan. Philip Kitley (2000) meneliti berita sepanjang dua minggu pada Desember 1991. Menggunakan sampel acak "dua minggu yang dirancang" dan kategorisasi Alfian dan Chu dalam studi terdahulu, ia mendapati $64,7 \%$ item data berita TVRI menyangkut peristiwa seremonial, dengan narasumber pejabat sebesar $53,32 \%$. Lebih lagi, $41 \%$ dari data merupakan kegiatan pembangunan berlokasi mayoritas $(64,49 \%)$ di Jakarta. Hal ini mendukung sentralisasi yang berpusat pada penguasa di masa Orde Baru.

Sementara itu, Sumita Tobing pada tahun yang sama melakukan studi tentang isi "berita pembangunan" dalam acara Berita Nusantara, Berita Nasional, dan Dunia Dalam Berita TVRI selama 14 hari. Tobing mendapati item berita pembangunan $54,7 \%$ dari total item berita. Pejabat pemerintah menjadi "aktor terkenal" dalam $55,7 \%$ item berita. Arswendo Atmowiloto juga mendapati dari total 909 siaran berita pada lima program berita TVRI selama April 1982, 68\% adalah berita menyangkut "pembukaan resmi" proyek pembangunan (1986, p. 35-41 dalam Kitley, 2000, p. 197). Temuan ini menunjukkan bagaimana TVRI waktu itu menjadi alat komunikasi penguasa Orde Baru. TVRI pada masa itu mendapat pendapatan dari pemerintah semata, dan dilarang menerima iklan. Pelarangan iklan menjadikan TVRI tergantung terhadap pemerintah, lumpuh sebagai alat kontrol sosial, dan menjadi apa yang disebut Althusser Ideological state apparatus (ISA). ISA berfungsi lewat ideologi, fungsinya menjelma sangat halus dan tersembunyi bahkan simbolik (Althusser, 1984).

Kedua, perubahan status TVRI. Fungsi propagandis TVRI secara tak langsung berakhir ketika rezim Orde Baru terguling. Setelah lahir reformasi, TVRI sempat berganti status beberapa kali: Perusahaan Jawatan (Juni 2000 melalui PP no. 36 tahun 2000), Perseroan (15 April 2003), hingga statusnya yang sekarang. Reformasi mengobarkan semangat demokratisasi penyiaran, sehingga hadir Undang Undang (UU) Penyiaran no.32/2002. Melalui UU Penyiaran, televisi di Indonesia dibagi menjadi empat bagian besar: Lembaga Penyiaran Publik (LPP), Lembaga Penyiaran Swasta (LPS), Lembaga Penyiaran Komunitas (LPK), dan Lembaga Penyiaran Berlangganan (LPB). TVRI sendiri berubah menjadi LPP.

Banyak harapan digantungkan di pundak TVRI sebagai LPP pertama negara ini. Effendy Gazali memaparkan, Lembaga Penyiaran Publik diharap menjadi pembanding, penyeimbang, bahkan sebagai check-point untuk akurasi yang lebih

${ }^{2}$ Propaganda merupakan usaha terorganisir dan kontinyu untuk mempengaruhi satu pemirsa massa, utamanya dengan menggunakan media massa (Kecskemeti, 1973; Qualter, 1962 dalam Larson, 2004, p.37). Sedangkan Jacques Ellul (dalam Nimmo, 2005) mendefinisikan propaganda sebagai komunikasi yang digunakan suatu kelompok terorganisasi yang ingin menciptakan partisipasi aktif maupun pasif dalam tindakan massa yang dipersatukan lewat manipulasi psikologis dalam organisasi. Tujuan propaganda, menurut Herbert Blumer (dalam Schramm, 1954) adalah menanamkan suatu sikap atau nilai yang perlahan dirasakan sebagai sesuatu yang alami, benar, seharusnya dan sewajarnya, sehingga dapat diekspresikan secara spontan dan tanpa paksaan. 
objektif daripada LPS atau Komersial yang dikhawatirkan berdampak negatif karena sarat adegan kekerasan, konflik, pemunculan narasumber tertentu terus menerus, serta mengakibatkan perubahan nilai-nilai lokal (Gazali dalam Gazali dkk., 2003, p. vii). Masyarakat berharap LPP mampu memenuhi kebutuhan keragaman program, dalam bahasa Mufid (2005): diversifikasi output tayangan demi pemberdayaan publik.

Ketiga, TVRI belum kuat secara finansial. Dalam pasal 15 ayat 1 UU Penyiaran disebutkan, LPP berhak menerima pendapatan dari beberapa sumber. Meski sumber pendapatan TVRI nampak beragam, TVRI merupakan pemain baru dalam dunia periklanan. Sejak krisis moneter melanda, kemampuan finansial pemerintah menopang TVRI merosot drastis, demikian pula iuran televisi yang diperolehnya (Sudibyo, 2004). Lambertus Hurek (2007) dalam wawancara dengan Kepala Stasiun TVRI Jatim, Iskandar Achmad memaparkan, dana pemerintah tidak mencukupi membiayai keperluan operasional dan pemeliharaan TVRI daerah, sehingga programprogram "kerjasama" diadakan untuk mempertahankan stasiun televisi pertama di Jatim ini. Program kerjasama ini dilakukan antara lain dengan pemerintah propinsi Jatim.

Sebagai contoh, dari anggaran TVRI nasional tahun 2006, TVRI Jatim menerima 13,2 miliar. Dari Rp 13,2 miliar, Rp 10,6 miliar habis untuk menggaji 412 karyawan yang 30 di antaranya honorer. Operasional dianggarkan sebesar Rp 2,6 miliar. Dari Rp 2,6 miliar itu, Rp 1,4 miliar habis untuk bahan bakar dan uang makan karyawan Rp 788 juta. Alhasil, program yang merupakan produk utama hanya mendapat anggaran sebesar Rp 133 juta (Hurek, 2007). Keterbatasan finansial ini membuat TVRI Jatim perlu membikin paket-paket kerjasama. Lebih lanjut Hurek menulis:

"Penyandang dana untuk membiayai program-program siaran yang diproduksi, memang diandalkan. Seperti Pemprov Jatim, sampai pada 2006 lalu masih mengucurkan dana sebesar Rp 750 juta. Dari anggaran itu, berbagai program dibuat untuk mendukung penyebaran informasi dari pihak penyandang dana." (2007, Ambruknya TVRI Jatim, 30 Maret)

Secara teoretis, penyandang dana turut mempengaruhi isi pemberitaan media. Hal ini seperti disampaikan oleh Altschull (dalam McQuail (2000, p.198) yang berpendapat, "The content of the media always reflects the interests of those who finance them" (Isi media selalu merefleksikan kepentingan siapa yang membiayainya). Maka, jika penyandang dana TVRI adalah masyarakat, melalui APBD yang dikucurkan negara, sudah pasti merefleksikan kepentingan negara (pemerintah). Sehingga isu kunjungan kerja Komisi A DPRD Jatim ke Belanda melalui pemberitaan TVRI Jatim menarik untuk diteliti. Sedangkan pemberitaan di JTV ${ }^{3}$ terkait dengan isu kunker Komisi A DPRD Jatim tersebut menarik juga untuk diteliti karena sebagai media swasta lokal bagaimana dalam menyikapinya. Dalam pengamatan peneliti, pemberitaan JTV cenderung mirip dengan Harian Jawa Pos. Hal ini dikarenakan filosofis JTV hampir sama dengan Jawa Pos. Pimred JTV Surya Aka (wawancara pribadi, 27 Mei 2008) mengatakan:

“...sebagai teve, kita kan berpikir bagaimana supaya dapat hidup, terima iklan, tetapi tetap independen. Jadi filosofisnya hampir sama dengan Jawa Poskebetulan pengasuh-pengasuh di JTV ini kan dari Jawa Pos juga,...”.

3 JTV merupakan televisi lokal di bawah naungan PT Jawa Media Televisi, yang sahamnya dimiliki Jawa Pos Group, salah satu kelompok media terbesar di Indonesia. 
Dari observasi peneliti selama Juli 2007 terkait pemberitaan kunker Komisi A, diperoleh data Jawa Pos memuat duabelas berita dan satu opini, mayoritas bernada kritik dan mendapat penonjolan cukup tinggi.

Oleh karena itu, alasan penelitian ini dilakukan karena isu berita kunker Komisi A DPRD Jatim mendapat sorotan media yang cukup tajam serta menimbulkan polemik. Sehingga rumusan masalah yang diambil adalah bagaimana bingkai berita kunjungan kerja Komisi A DPRD ke Belanda terkait hari jadi Jatim dalam TVRI Jatim dan JTV?. Dimana penelitian ini diharapkan mampu memberikan kontribusi pada studi analisis bingkai media (framing analysis) pada Lembaga Penyiaran Publik TVRI Jawa Timur dan JTV, khususnya dalam berita Pemerintah Propinsi yang selama ini mungkin belum atau kurang dicermati dalam penelitian-penelitian terdahulu. Penelitian diharap dapat memberi gambaran konsep dan teori dalam mengamati bingkai pemberitaan.

Paradigma penelitian ini adalah interpretif dengan pendekatan penelitian kualitatif, dimana penelitian kualitatif memiliki karakteristik antara lain: memberikan penilaian (evaluatif) menggunakan konsep dalam analisisnya secara teoretis, menginterpretasi, berujung pada evaluasi, dan interpretasi dapat diperdebatkan (Berger, 2000). Sedangkan metode yang digunakan analisis framing (bingkai) model Zhongdang Pan dan Gerard M. Kosicki. Framing analysis.

Sasaran penelitian ini adalah berita kunjungan kerja Komisi A DPRD Jatim ke Belanda terkait pencarian data hari jadi Propinsi Jatim di TVRI Jawa Timur dan JTV; bagaimana TVRI Jatim dan JTV membingkai peristiwa: menekankan bagian tertentu, melakukan seleksi dan menghubungkan bagian tertentu. Subyek penelitian dibatasi pada program berita "Jatim dalam Berita" di TVRI dan program berita "Pojok Pitu" di JTV. Kedua program berita tersebut merupakan buletin unggulan masingmasing televisi. Unit analisis yang digunakan dibatasi pada naskah berita dan gambar berita TVRI 25 Juli 2007 dan 23 Oktober 2007 serta naskah berita JTV 10 Juli 2007. Dimana peneliti menggunakan unit analisis empat struktur besar perangkat bingkai Zhongdang Pan dan Gerard M. Kosicki.

Menurut Pan dan Kosicki, keempat struktur tersebut adalah struktur sintaksis, struktur skrip, struktur tematik, dan struktur retoris. Teknik pengumpulan data secara primer (berupa naskah dan gambar berita TVRI Jatim dan JTV ) dan data sekunder (studi literatur, buku, arsip, dokumen dan sebagainya yang mendukung penelitian). Sedangkan dalam teknik analisis triangulasi data.

\section{PEMBAHASAN}

Konstruktivisme, merupakan suatu doktrin di mana persepsi, ingatan, dan struktur mental kompleks lainnya disusun secara aktif oleh pikiran (Colman, 2001, Dictionary of Psychology). Jadi persepsi, ingatan, dan struktur mental kompleks tersebut dikonstruksi secara aktif, bukan realitas obyektif yang tersedia di hadapan kita sehingga kita memperolehnya secara alami begitu saja. Gagasan mengenai konstruktivisme pertama dimunculkan psikolog Inggris Sir Frederic Charles Bartlett tahun 1932 untuk menjelaskan fenomena temuannya tentang ingatan manusia. Kemudian berkembang di tangan psikolog seperti Richard Ulrich (konstruksi terkait persepsi), Richard Gregory (konstruksi pikiran sebagai penyebab ilusi visual), dan Jean Piaget (konstruksi mental dalam diri anak-anak) (Colman, 2001). 
Konstruktivisme sosial sendiri, pertama kali dipopulerkan Peter Ludwig Berger dan Thomas Luckmann melalui buku The Social Construction of Reality, terbit tahun 1966. Inti gagasan konstruksi sosial realitas Berger dan Luckmann adalah, realitas dikonstruksi secara sosial. Realitas di sini diwujudkan antara lain sebagai kejadian hidup sehari-hari. Menggambarkan kenyataan hidup sehari-hari, Berger menulis:

"Kenyataan hidup sehari-hari diterima begitu saja sebagai kenyataan. Ia tidak memerlukan verifikasi tambahan selain kenyataannya yang sederhana. Ia memang sudah ada di sana, sebagai faktisitas yang memaksa dan sudah jelasdengan-sendirinya...Meskipun saya dapat menyangsikan kenyataannya, saya merasa wajib untuk menangguhkan kesangsian seperti itu selama saya bereksistensi secara rutin dalam kehidupan sehari-hari. Penangguhan kesangsian itu begitu kuat sehingga untuk mencabutnya..., saya harus melakukan suatu peralihan yang sangat besar.” (Berger dan Luckmann, 1990, p. 34)

Realitas sosial adalah hasil konstruksi, dimana mengutip kalimat Berger dalam bukunya Invitation to Sociology (1963 dalam Brigham, 1998), "Social reality turns out to have many layers of meaning. The discovery of each new layer changes the perception of a whole." (Realitas sosial terbukti memiliki beragam lapis makna. Penemuan tiap lapis baru mengubah persepsi keseluruhan). Realitas sosial terdiri dari berlapis pemaknaan yang dikonstruksi oleh masyarakat, dan lapisan-lapisan itu membentuk kehidupan sehari-hari yang familier dan terkesan normal. Normalitas inilah yang ingin dibongkar penganut konstruktivisme. Mengutip N. Goodman, dunia sehari-hari dikonstruksi individu melalui beragam pengetahuan yang dimilikinya (Goodman, 1978 dalam Flick, 1998).

Berita, dalam pandangan konstruktivis, bukanlah realitas obyektif yang semata hadir di luar sana, yang disajikan oleh organisasi media sebagaimana adanya. Berita bukan sekedar serangkaian tulisan yang disusun rapi dalam halaman suratkabar, yang bisa kita nikmati setiap pagi sambil minum kopi dan sarapan. Berita bukan sekedar serangkaian peristiwa di luar sana, yang disampaikan reporter berita di layar kaca, yang kita dengarkan sambil menyiapkan makan malam atau menemani kita membersihkan rumah. Kehadiran berita melalui medium, seringkali telah begitu biasa kita jumpai dalam kehidupan sehari-hari, sehingga kita menerimanya begitu saja, taken for granted. Seiring dengan kalimat Schütz yang menyatakan tidak ada fakta yang murni dan sederhana, demikian pula tidak ada berita, yang murni dan sederhana.

Teks berita, menurut paradigma konstruktivis adalah hasil konstruksi realitas (Eriyanto, 2002). Realitas hadir, tercipta lewat konstruksi, sudut pandang tertentu wartawan (Eriyanto, 2002). Berita, menurut pandangan konstruktivisme adalah produk interaksi wartawan dengan fakta (Eriyanto, 2002). Berita juga hasil produksi organisasi. Realitas yang melanda wartawan diserap untuk kemudian dieksternalisasi sebagai produk pemaknaan. Oleh sebab itu, penganut konstruktivisme berpendapat, fakta atau peristiwa adalah hasil konstruksi. Realitas bukan sesuatu yang ada di luar dan tinggal diambil. Realitas tercipta lewat konstruksi dan sudut pandang tertentu wartawan. 
Analisis bingkai media tidak lepas dari paradigma kontruktivis dimana menurut Zhongdang Pan dan Gerald M. Kosicki (dalam Eriyanto, 2002, p.255-266) perangkatnya menggunakan teknik analisis struktur besar, yaitu:

1. Struktur sintaksis, berhubungan dengan bagaimana wartawan menyusun peristiwa ke dalam bentuk umum berita. Unit analisis sintaksis adalah headline, lead, latar informasi, kutipan sumber, pernyataan, dan penutup.

2. Struktur skrip, berhubungan dengan cara wartawan mengisahkan peristiwa ke dalam bentuk berita. Struktur ini melihat bagaimana strategi cara bercerita wartawan dalam mengemas berita melalui $5 \mathrm{~W}+1 \mathrm{H}$.

3. Struktur tematik, berhubungan dengan bagaimana mengungkapkan pandangannya atas peristiwa dalam paragraf, proposisi, kalimat, dan hubungan antar kalimat, bagaimana pemahaman diwujudkan dalam bentuk yang lebih detil atau kecil.

4. Struktur retoris, berhubungan dengan upaya wartawan menekankan arti tertentu lewat leksikon, grafis, dan metafora berita. Unsur ini bukan hanya mendukung tulisan tapi juga menekankan arti tertentu pada khalayak.

Temuan dalam penelitian ini adalah TVRI Jatim dalam struktur sintaksisnya berita terkait kunjungan kerja Komisi A DPRD Jatim ke Belanda kurang penting. TVRI menonjolkan pendapat narasumber dari pemerintah. TVRI juga menonjolkan kesan positif profil narasumber dari pemerintah. Sementara narasumber non pemerintah kurang mendapat penonjolan serupa. Sedangkan televisi swasta lokal JTV dalam struktur sintaksisnya memberi kesan bahwa berita terkait penemuan bukti sejarah hari jadi Jatim oleh sejarawan penting. JTV menonjolkan temuan narasumber non pemerintah untuk memperbandingkan dengan hasil kunker pemerintah.

TVRI Jatim dalam struktur skripnya memaparkan kontroversi adanya pro kontra seputar kunker, pada bagian awal berita. Sehingga seolah hendak membawa pemirsa mengetahui perkara pro kontra. Namun makin lama, TVRI tidak membahas tentang pro kontra kunker, melainkan menonjolkan peristiwa presentasi Komisi A DPRD Jatim dari sudut pandang pemerintah dalam hal ini Komisi A. JTV sebaliknya, memaparkan peristiwa dari sisi narasumber dan mengkontroversikan dengan pihak pemerintah untuk mendelegitamasi Komisi A atas isu kunker.

TVRI Jatim dalam struktur tematiknya, menggunakan detail historis yuridis untuk mendukung pernyataan wartawan yang menonjolkan temuan Komisi A sebagai keberhasilan. Sementara JTV menggunakan detail historis yuridis untuk menonjolkan kesahihan temuan narasumber Soedarman. Dengan demikian JTV secara halus hendak menyampaikan pesan kepada pemirsa bahwa kunker Komisi A sia-sia. TVRI dalam struktur retorisnya menggunakan unsur wacana dan retorika untuk menonjolkan tindakan aktif pemerintah lewat Komisi A dalam upaya menemukan data hari jadi Jatim. Sementara JTV menggunakan unsur wacana dan retorika untuk menonjolkan bukti temuan Soedarman sebagai keberhasilan, sehingga penonjolan pesan kunker Komisi A sia-sia. Lebih jelasnya dapat dilihat dalam matrik perbedaan bingkai berita kunker di TVRI Jatim dan JTV berikut ini: 
Tabel 1. Matriks Perbedaan Bingkai Berita Kunker Komisi A TVRI dan JTV

\begin{tabular}{|c|c|c|c|}
\hline $\begin{array}{l}\text { Struktur } \\
\text { Teks }\end{array}$ & $\begin{array}{c}\text { Unit } \\
\text { Pengamatan }\end{array}$ & TVRI & JTV \\
\hline \multicolumn{2}{|c|}{ Struktur Sintaksis } & $\begin{array}{l}\text { TVRI tidak memasukkan berita } \\
\text { kedalam headline; cenderung } \\
\text { mengulas peristiwa dari sudut } \\
\text { pandang pemerintah, versi } \\
\text { pemerintah }\end{array}$ & $\begin{array}{l}\text { JTV memasukkan berita } \\
\text { kedalam headline; } \\
\text { cenderung mengulas } \\
\text { peristiwa dari sudut } \\
\text { pandang pembuat berita: } \\
\text { temuan sejarawan sahih } \\
\text { dan kunker sia-sia }\end{array}$ \\
\hline & Headline & $\begin{array}{l}\text { Tidak masuk HL, judul deskriptif, } \\
\text { tak ada perluasan wacana }\end{array}$ & $\begin{array}{l}\text { Masuk HL, judul deskriptif, } \\
\text { menunjukkan ada sesuatu } \\
\text { yang signifikan terjadi }\end{array}$ \\
\hline & Lead & $\begin{array}{l}\text { Mengesankan hendak membahas } \\
\text { isu signifikan bagi masyarakat }\end{array}$ & $\begin{array}{l}\text { Mempertautkan peristiwa } \\
\text { dengan peristiwa lain } \\
\text { (kunker), menonjolkan } \\
\text { pendapat wartawan, } \\
\text { mempertentangkan } \\
\text { penemuan Soedarman } \\
\text { dengan kunker dewan. }\end{array}$ \\
\hline \multicolumn{2}{|r|}{ Latar informasi } & $\begin{array}{l}\text { Menonjolkan tindakan aktif } \\
\text { pemerintah dalam menyelesaikan } \\
\text { masalah. }\end{array}$ & $\begin{array}{l}\text { Elaborasi proses penemuan } \\
\text { dan hasil temuan } \\
\text { sejarawan; menekankan } \\
\text { keabsahan temuan dan } \\
\text { kesia-siaan kunker }\end{array}$ \\
\hline \multicolumn{2}{|r|}{ Kutipan sumber } & $\begin{array}{l}\text { Menonjolkan narasumber } \\
\text { pemerintah dan pandangannya. }\end{array}$ & $\begin{array}{l}\text { Mengklaim validitas } \\
\text { pernyataan berdasar } \\
\text { keahlian sejarawan; } \\
\text { menonjolkan kredibilitas } \\
\text { sejarawan dan temuannya; } \\
\text { mendukung gagasan } \\
\text { wartawan kunker sia-sia }\end{array}$ \\
\hline \multicolumn{2}{|r|}{ Pernyataan } & $\begin{array}{l}\text { Menekankan signifikansi } \\
\text { tindakan pemerintah, } \\
\text { menonjolkan pemerintah sebagai } \\
\text { pelaku aktif, signifikansi berita, } \\
\text { mendorong pemirsa simpati pada } \\
\text { pemerintah. }\end{array}$ & $\begin{array}{l}\text { Menonjolkan pendapat } \\
\text { wartawan menggunakan } \\
\text { majas dan leksikon }\end{array}$ \\
\hline \multicolumn{2}{|r|}{ Penutup } & $\begin{array}{l}\text { Menonjolkan tindak lanjut } \\
\text { pemerintah, atau sekedar } \\
\text { menutup berita. }\end{array}$ & $\begin{array}{l}\text { Mengesankan pemberitaan } \\
\text { JTV seolah ada evaluasi sisi } \\
\text { negatif dan positif secara } \\
\text { seimbang, tapi pada } \\
\text { akhirnya tetap } \\
\text { mengukuhkan profil } \\
\text { narasumber; } \\
\text { mendelegitimasi } \\
\text { pemerintah }\end{array}$ \\
\hline Struktur Skr & & $\begin{array}{l}\text { Cenderung berpihak pada versi } \\
\text { pemerintah. Di awal terkesan } \\
\text { memaparkan pro dan kontra }\end{array}$ & $\begin{array}{l}\text { Cenderung berpihak pada } \\
\text { versi wartawan. } \\
\text { Memperlawankan kunker }\end{array}$ \\
\hline
\end{tabular}




\begin{tabular}{|c|c|c|c|}
\hline \multirow{2}{*}{\multicolumn{2}{|c|}{$\begin{array}{c}\text { Struktur } \\
\text { Teks }\end{array}$}} & TVRI & JTV \\
\hline & & $\begin{array}{l}\text { kunker yang masih terjadi, } \\
\text { namun makin lama memaparkan } \\
\text { argumen dan sudut pandang } \\
\text { pemerintah }\end{array}$ & $\begin{array}{l}\text { dengan temuan sejarawan } \\
\text { di awal, memaparkan } \\
\text { keterangan narasumber } \\
\text { dan versi peristiwa dari } \\
\text { sudut pandang opini } \\
\text { wartawan, didukung } \\
\text { argumen-argumen legal } \\
\text { sejarah. }\end{array}$ \\
\hline & $\begin{array}{l}\text { Cara } \\
\text { mengisahkan } \\
\text { fakta }\end{array}$ & $\begin{array}{l}\text { Di awal terkesan memaparkan } \\
\text { argumen berbeda (cover both } \\
\text { sides), pada akhir lebih } \\
\text { memaparkan peristiwa dari versi } \\
\text { pemerintah }\end{array}$ & $\begin{array}{l}\text { Memperlawankan } \\
\text { sejarawan dan pemerintah } \\
\text { di awal dan akhir teks; } \\
\text { tidak memperlihatkan } \\
\text { konflik secara eksplisit; } \\
\text { lebih banyak memaparkan } \\
\text { peristiwa dari sudut } \\
\text { pandang wartawan } \\
\text { didukung pernyataan dan } \\
\text { data-data }\end{array}$ \\
\hline & Siapa & $\begin{array}{l}\text { Narasumber pemerintah sebagai } \\
\text { pemain kunci berita }\end{array}$ & $\begin{array}{l}\text { Narasumber non } \\
\text { pemerintah sebagai } \\
\text { narasumber tunggal } \\
\end{array}$ \\
\hline & Apa & $\begin{array}{l}\text { Persoalan yang dihadapi dilihat } \\
\text { dari versi pemerintah atau } \\
\text { sekedar deskripsi peristiwa }\end{array}$ & $\begin{array}{l}\text { Menggabungkan tindakan } \\
\text { dewan dan sejarawan } \\
\text { sehingga posisinya terkesan } \\
\text { sama. Namun Komisi A } \\
\text { digambarkan melakukan } \\
\text { kegiatan sia-sia tapi } \\
\text { Soedarman berhasil }\end{array}$ \\
\hline & Kapan & Baru terjadi & Baru terjadi \\
\hline & Di mana & $\begin{array}{l}\text { Berita tampaknya telah terjadwal } \\
\text { sebelumnya }\end{array}$ & Berita hangat \\
\hline & Mengapa & Menonjolkan versi pemerintah & $\begin{array}{l}\text { Mendukung versi kunker } \\
\text { sia-sia }\end{array}$ \\
\hline & Bagaimana & $\begin{array}{l}\text { Mengemukakan kemajuan } \\
\text { kegiatan pemerintah. }\end{array}$ & $\begin{array}{l}\text { Mendukung tema kunker } \\
\text { sia-sia }\end{array}$ \\
\hline Struktur Tem & atik & $\begin{array}{l}\text { TVRI menggunakan tema-tema } \\
\text { yang mendukung pemerintah } \\
\text { menggunakan detil fakta legal } \\
\text { yuridis - historis untuk } \\
\text { mendukung pernyataan, sehingga } \\
\text { mengesankan pemerintah sebagai } \\
\text { bagian dari pemirsa telah } \\
\text { bertindak aktif dalam } \\
\text { menyelesaikan persoalan hari jadi } \\
\text { Jatim. }\end{array}$ & $\begin{array}{l}\text { Tema-tema yang ada } \\
\text { mengkritik atau dan } \\
\text { mendelegitimasi kunker } \\
\text { Komisi A dan melegitimasi } \\
\text { a temuan hari jadi oleh } \\
\text { i sejarawan } \\
\text { i }\end{array}$ \\
\hline & Detail & $\begin{array}{l}\text { Memaparkan fakta-fakta legal } \\
\text { yuridis sejarah untuk mendukung } \\
\text { tema-tema berita yang pro } \\
\text { pemerintah }\end{array}$ & $\begin{array}{l}\text { Memaparkan fakta-fakta } \\
\text { legal sejarah untuk } \\
\text { mendukung tema berita } \\
\text { yang anti pemerintah }\end{array}$ \\
\hline
\end{tabular}




\begin{tabular}{|c|c|c|c|}
\hline \multirow[t]{5}{*}{$\begin{array}{c}\text { Struktur } \\
\text { Teks } \\
\end{array}$} & $\begin{array}{c}\text { Unit } \\
\text { Pengamatan }\end{array}$ & TVRI & JTV \\
\hline & & & (kunker sia-sia) \\
\hline & Koherensi & $\begin{array}{l}\text { Mendukung tema berita yang pro } \\
\text { pemerintah }\end{array}$ & $\begin{array}{l}\text { Mendukung tema berita } \\
\text { yang anti kunker }\end{array}$ \\
\hline & Bentuk kalimat & $\begin{array}{l}\text { Komisi A dikesankan sebagai } \\
\text { pelaku aktif, mendukung tema } \\
\text { berita yang pro pemerintah }\end{array}$ & $\begin{array}{l}\text { Didominasi kalimat aktif, } \\
\text { menonjolkan penemuan } \\
\text { Soedarman: proses, asal, } \\
\text { dan kesan kesahihan } \\
\text { temuannya. }\end{array}$ \\
\hline & Kata Ganti & $\begin{array}{l}\text { Kata ganti membuat kalangan } \\
\text { non pemerintah sebagai "mereka" } \\
\text { dan Komisi A sebagai "kita" }\end{array}$ & $\begin{array}{l}\text { Menciptakan alienasi } \\
\text { antara pemirsa dan } \\
\text { pemerintah, solidaritas } \\
\text { antara pemirsa dan } \\
\text { Soedarman } \\
\end{array}$ \\
\hline \multirow[t]{5}{*}{ Struktur Retc } & & $\begin{array}{l}\text { Cenderung memanfaatkan unsur } \\
\text { wacana untuk mendukung pesan } \\
\text { berita untuk menonjolkan upaya } \\
\text { pemerintah. Klaim-klaim, pilihan } \\
\text { kata, gambar, menonjolkan } \\
\text { tindakan aktif pemerintah, } \\
\text { keberhasilan pembangunan; } \\
\text { mengesankan ada persamaan visi } \\
\text { antar pemirsa dan pemerintah; } \\
\text { menenggelamkan kontroversi }\end{array}$ & $\begin{array}{l}\text { Cenderung memanfaatkan } \\
\text { unsur wacana untuk } \\
\text { menonjolkan keberhasilan } \\
\text { Soedarman sehingga } \\
\text { mendukung pesan kunker } \\
\text { sia-sia. Menggunakan diksi, } \\
\text { lesikon, grafis, metafora } \\
\text { yang menegaskan secara } \\
\text { implisit pernyataan } \\
\text { wartawan: kunker sia-sia } \\
\end{array}$ \\
\hline & Retorika & $\begin{array}{l}\text { Klaim yuridis sejarah } \\
\text { menekankan } \\
\text { kesahihan/signifikansi } \\
\text { peristiwa/pernyataan wartawan; } \\
\text { eufemisme konflik; pemerintah } \\
\text { dikesankan protagonis }\end{array}$ & $\begin{array}{l}\text { Diksi menonjolkan } \\
\text { kesahihan penemuan } \\
\text { Soedarman; } \\
\text { mendelegitimasi kunker } \\
\text { dewan }\end{array}$ \\
\hline & Leksikon & $\begin{array}{l}\text { Pemerintah dikesankan positif; } \\
\text { kesan konflik diminimalkan } \\
\text { dengan pilihan kata }\end{array}$ & $\begin{array}{l}\text { Menekankan kesia-siaan } \\
\text { kunker dan keberhasilan } \\
\text { temuan sejarawan }\end{array}$ \\
\hline & Grafis & $\begin{array}{l}\text { Pemerintah dikesankan aktif, } \\
\text { paternalistik; menimbulkan rasa } \\
\text { kedekatan antara pemirsa dengan } \\
\text { pemerintah dalam berita; } \\
\text { menonjolkan keberhasilan } \\
\text { pembangunan; memberi kesan } \\
\text { kesatuan visi antara pemerintah } \\
\text { dan pemirsa (masyarakat); } \\
\text { menimbulkan aliansi pemirsa }\end{array}$ & $\begin{array}{l}\text { Mendukung tema berita } \\
\text { yang mendelegitimasi } \\
\text { kunker dewan dan } \\
\text { melegitimasi temuan } \\
\text { Soedarman }\end{array}$ \\
\hline & Metafora & $\begin{array}{l}\text { Tidak pakai, hanya majas yang } \\
\text { digunakan untuk menekankan } \\
\text { hal-hal yang mendukung } \\
\text { tindakan pemerintah dan } \\
\text { menenggelamkan yang terkesan } \\
\text { kontroversial bagi pemerintah }\end{array}$ & $\begin{array}{l}\text { Perlawanan biner antara } \\
\text { masa sebelum (simpang } \\
\text { siur) dan sesudah (titik } \\
\text { kejelasan) yang berfungsi } \\
\text { menonjolkan signifikansi } \\
\text { penemuan Soedarman }\end{array}$ \\
\hline
\end{tabular}




\section{Media dalam Konteks Historis, Yuridis, dan Sosiologis}

Bingkai TVRI dalam pemberitaannya memperlihatkan kecenderungan berpihak terhadap versi pemerintah, mengajak pemirsa bersimpati terhadap pemerintah. TVRI seolah menjadi saluran berita versi pemerintah. Kecenderungan untuk menonjolkan cerita versi pihak pemerintah dilakukan melalui pemilihan narasumber dan peletakan kutipan, tema-tema yang diusung berita, cara pemaparan fakta, hingga penggunaan elemen wacana dalam kalimat yang memberi kesan netral cenderung berpihak kepada pemerintah.

Sedangkan JTV dalam pemberitaannya memperlihatkan kecenderungan menonjolkan peristiwa menurut versi wartawan, kontra kunker dan mendelegitimasi pemerintah. Kecenderungan untuk menonjolkan peristiwa dari sudut pandang wartawan ini dilakukan melalui penggunaan elemen wacana seperti kalimat, kutipan narasumber, pemaparan detail pendukung, tema-tema yang diusung berita. Melalui penggunaan elemen-elemen tersebut sedemikian rupa memperbandingkan penemuan data sejarawan dengan kunker pemerintah, JTV memberi penonjolan pada kegagalan pemerintah. Penonjolan ini digunakan untuk mendukung ide berita: kritik terhadap kunker dan asumsi kelalaian pemerintah.

Melalui struktur sintaksis, skrip, tematik, dan retoris yang diamati, kedua media ini menurut peneliti, sama-sama kurang memperhatikan hak dan tanggungjawab sebagai penyampai pesan yang harusnya dapat lebih fair bagi khalayak. Media, meski tak dipungkiri bukan merupakan cermin realitas, seyogyanya mengusahakan pemberitaan yang berimbang demi kepentingan khalayak yang frekuensinya dipergunakan. Walter Lippman (dalam Broeder, 1992) mengatakan, meski obyektifitas tak dapat diterapkan secara kaku, obyektifitas diperlukan untuk memampukan pers melakukan perlawanan "terhadap upaya melacurkan pers yang dilakukan oleh kelompok penguasa politik, ekonomi, dan ideologi...” Jadi obyektifitas, meski tak mutlak dilakukan, tetap diperlukan demi kepentingan kebebasan pers itu sendiri. Bukan pers sebagai institusi melainkan pers sebagai profesi dan kebebasan pers sebagai hak asasi wartawan, memberi kendali pekerja media memberitakan fakta dan melawan pencemaran vested interest dalam berita.

Untuk menjelaskan fenomena-fenomena tersebut, peneliti melakukan telaah sejarah, legal yuridis, dan sosiologi media terhadap TVRI dan JTV. TVRI, dalam sejarah perjalanannya, diwarnai dengan tarik-menarik kepentingan antara rejim berkuasa dan usaha menjadi stasiun yang lebih independen. TVRI didirikan bagi kepentingan komunikasi Orde Lama dan Orde Baru, sehingga seolah tak berkutik dari cengkeraman program-program propaganda pembangunan pemerintah. TVRI pada masa Orde Baru bergantung pada pemerintah, dalam memberitakan peristiwa yang menurut Departemen Penerangan waktu itu layak diberitakan. Akibatnya, selama bertahun-tahun TVRI terpaku pada dominasi pemberitaan pemerintah, dan berita-berita yang mengunggulkan kegiatan pemerintah. Peristiwa ketidakberesan dan penyelewengan pemerintah menurut peneliti sudah pasti tidak akan muncul di TVRI, karena indoktrinasi yang kuat sebagai alat persatuan dan kesatuan bangsa.

Studi yang dilakukan Alfian dan Chu, Arswendo Atmowiloto, Sumita Tobing, memperlihatkan bahwa selama dua dasawarsa Orde Baru berita nasional di TVRI berisi seremonial terutama terpaku pada perayaan ritual kegiatan dan etos pembangunan dari pemerintah. Philip Kitley dalam penelitian selama dua minggu 
tahun 1991 juga mendapati bagaimana pejabat pemerintah mendominasi 53,52\% pemberitaan, di mana pusat pemerintahan menempati sekurangnya satu dari lima berita dan presentase berita seremonial 82,75\% dari keseluruhan pemberitaan (Kitley, 2000). Kitley memaparkan fenomena ini, dan menulis: "Berita nasional menjadi wahana utama representasi simbolik dari pengutamaan pembangunan dalam proyek budaya pembangunan" (Kitley, 2000, p.197). Bentuk pakem pemberitaan demikian terjadi selama bertahun-tahun, sehingga menurut peneliti, bingkai tersebut masih terdapat dalam membuat berita di TVRI. Faktor sejarah sebagai media propaganda pemerintah ini berperan membentuk citra TVRI yang masih terkesan menonjolkan peristiwa versi pemerintah dalam kasus Kunker.

Selain faktor sejarah, faktor legal yuridis juga mempengaruhi bentuk media, dan pada akhirnya mempengaruhi bentuk produk medianya. Undang Undang Penyiaran No. 32 tahun 2002 membagi lembaga penyiaran di Indonesia menjadi empat yaitu Lembanga Penyiaran Publik (LPP4), Lembaga Penyiaran Swasta (LPS), Lembaga Penyiaran Berlangganan (LPB), dan Lembaga Penyiaran Komunitas (LPK). TVRI Jatim dalam perspektif Undang Undang Penyiaran nomor 32/2002 menjadi Lembaga Penyiaran Publik yang didefinisikan sebagai: Lembaga penyiaran yang berbentuk badan hukum yang didirikan oleh negara, bersifat independen, netral, tidak komersial, dan berfungsi memberikan layanan untuk kepentingan masyarakat. TVRI dan RRI boleh mendirikan Lembaga Penyiaran Publik lokal di daerah propinsi, kabupaten atau kota.

Dalam perundangan ini, peneliti mencermati adanya peran pemerintah dalam pendirian dan penegakan LPP. Peran tersebut antara lain: negara sebagai pendiri LPP; dewan pengawas dipilih DPR/DPRD atas usul pemerintah /dan masyarakat dan diangkat eksekutif; LPP diawasi oleh DPR/DPRD; sumber dana antara lain dari

4 LPP memiliki dewan pengawas dan dewan direksi yang dibentuk sesuai peraturan perundangan yang berlaku (pasal 14 ayat 4). Dewan pengawas ditetapkan aparatur eksekutif setelah melalui uji kelayakan, atas usul lembaga legislatif berdasar masukan pemerintah dan/atau masyarakat. Jumlah anggotanya 5 orang (nasional) dan 3 orang (lokal), dengan fungsi mengangkat dan menetapkan dewan direksi. Dewan direksi dan dewan pengawas memiliki masa kerja 5 tahun dan boleh dipilih kembali untuk 1 kali masa kerja. LPP di tingkat pusat diawasi Dewan Perwakilan Rakyat RI (DPR RI), sedangkan LPP di tingkat lokal diawasi DPR Daerah (DPRD). Sumber pembiayaan LPP berasal dari lima sumber: iuran penyiaran, APBN (LPP Pusat) atau APBD (LPP Lokal), sumbangan masyarakat, siaran iklan, dan usaha lain yang sah terkait dengan penyelenggaraan siaran (pasal 15 ayat 1). Pada akhir tahun anggaran, LPP wajib membuat laporan keuangan yang diaudit akuntan publik dan hasilnya diumumkan di media massa (pasal 15 ayat 2). Tugas LPP disebutkan antara lain menyiarkan program siaran yang berisi informasi, pendidikan, hiburan, dan manfaat untuk pembentukan intelektualitas, watak, moral, kemajuan, kekuatan bangsa, menjaga persatuan dan kesatuan, serta mengamalkan nilai-nilai agama dan budaya Indonesia (pasal 36 ayat 1). LPP Lokal juga wajib memuat sekurangnya $60 \%$ mata acara yang berasal dari dalam negeri (pasal 36 ayat 2). Selain itu, isi siaran wajib memberikan perlindungan dan pemberdayaan kepada khalayak khusus, yaitu anak-anak dan remaja, dengan menyiarkan mata acara pada waktu yang tepat, dan lembaga penyiaran wajib mencantumkan dan atau menyebutkan klasifikasi khalayak sesuai dengan isi siaran (pasal 36 ayat 3 ). 
APBN/APBD; tujuan program siaran LPP antara lain untuk kemajuan kebangsaan, menjaga persatuan dan kesatuan, serta mengamalkan "agama" dan "budaya Indonesia"; serta program LPP diharuskan minimal 60\% berasal dari dalam negeri. Peran pemerintah dapat dipandang sebagai tanggungjawab sosial pemerintah kepada rakyatnya, untuk menjamin adanya saluran media yang jauh dari kepentingan komersial dan bertujuan semata-mata mengembangkan khalayaknya.

Namun di sisi lain, peran pemerintah yang cukup besar dapat mempengaruhi LPP sehingga tidak menjadi lembaga penyiaran yang netral dan independen bagi masyarakat, tetapi menjadi media komunikasi pemerintah -menyalurkan apa yang menurut pemerintah baik dan penting untuk diberitakan. Jumlah program yang minimal 60\% lokal di satu sisi mengindikasikan kekuatiran pemerintah akan dampak pengaruh program dari luar negeri, dan dampaknya, TVRI sebagai LPP akan mengeluarkan biaya dan tenaga yang lebih besar untuk memproduksi program. Biaya dan tenaga yang lebih besar akan memperbesar kebutuhan dana. Sementara dana terbesar LPP didapat dari pemerintah. Jadi program produksi sendiri yang lebih banyak dapat berarti ketergantungan lebih besar terhadap pemerintah untuk mendanai LPP.

Demikian pula, pertanggungjawaban terhadap DPR/DPRD dapat menambah keseganan LPP membahas ketidakberesan dalam diri pemerintah. Faktor-faktor legal-yuridis semacam ini, meski dapat berpengaruh positif jika dijalankan dalam tataran demokratis yang transparan, dapat berpengaruh negatif jika LPP yang dimaksudkan menjadi lembaga penyiaran publik netral, independen, dan tidak komersial, menjadi lembaga penyiaran yang terikat pada pemerintah, atau malah menjadi saluran komunikasi pemerintah semata. Faktor legal-yuridis ini juga yang menurut peneliti turut berperan membentuk pemberitaan TVRI yang terkesan kurang lugas membahas kontroversi dan ketidakberesan kunker dan hari jadi, menonjolkan peristiwa dari sudut pandang pihak pemerintah.

Selain dari aspek sejarah dan legal yuridis, pemberitaan media juga dipengaruhi oleh sosiologi medianya. Shoemaker dan Reese (1996), mengkategorisasikan pengaruh-pengaruh pemberitaan media menjadi lima: pengaruh dari individu wartawan pencari berita, rutinitas organisasi, struktur organisasi, kekuatan ekstramedia, dan ideologi. Pengaruh individu yang dimaksud adalah latar belakang wartawan: pengalaman kerja, pendidikan, status sosial, jender, etika kerja, etnisitas, agama, hingga orientasi seksual, juga sikap pribadi wartawan mengenai peristiwa, nilai yang dipegang, dan kepercayaan yang ia pegang teguh. Wartawan yang memberitakan peristiwa terkait kunker dan hari jadi Jatim di TVRI umumnya telah berada di TVRI sejak masa Orde Baru. Mengutip Ashadi Siregar (1995), TVRI selama tiga dasawarsa berusaha memformat masyarakat Indonesia untuk menerima standar kelayakan berita versi birokrasi.

Salah satu aturan tak tertulis yang mengharuskan media mendukung pemerintah Orde Baru adalah aturan untuk tidak memberitakan hal-hal negatif mengenai pemerintah. Konsepsi tak tertulis mengenai apa yang boleh diberitakan dan tidak tentang pemerintah ini dapat dijelaskan dengan pendapat sosiolog Herbert J. Gans yang mengatakan, pemerintah umumnya mendambakan kerahasiaan, dan keberadaannya tergantung pada seberapa besar pemerintah dapat menciptakan konsensus (Broeder, 1992). Untuk menyalurkan berita berstandar kelayakan birokrasi, rezim yang berkuasa perlu memformat organisasi media yang 
digunakannya supaya menerima standar berita versi pemerintah kala itu. Organisasi di sini termasuk pula individu-individu di dalam TVRI. Pengalaman di-format oleh rezim Orde Baru, ditambah status sebagai pegawai negeri, yang membuat wartawan TVRI mampu mengidentifikasi peran sebagai bagian dari pemerintah dengan baik, menurut peneliti, turut mempengaruhi pemberitaan TVRI yang cenderung bersimpati pada pemerintah, menonjolkan peristiwa dari sudut pandang pemerintah.

Lambertus Hurek (2007) dalam wawancara dengan Kepala Stasiun TVRI Jatim, Iskandar Achmad, memaparkan: dana pemerintah tidak mencukupi membiayai keperluan operasional dan pemeliharaan TVRI daerah, sehingga program-program "kerjasama" diadakan untuk mempertahankan stasiun televisi pertama di Jatim ini. Program kerjasama ini dilakukan antara lain dengan pemerintah propinsi Jatim, yaitu dengan paket produksi biaya rendah, seperti Lintas Arena, Liputan Berita Pembangunan Jatim, OTODA, Interaktif, Ajang Wadul, Jer Basuki Mawa Beya, Kabar Dari Desa. Sebagai catatan, ketujuh program ini bisa dibilang berhenti produksi per 2007 karena Pemprov menghentikan kerjasama. Sebagian masih dipertahankan, misalnya Kabar dari Desa yang masih tayang, meski hanya pengulangan dari yang sudah-sudah. Per Juni 2007, TVRI Jatim masih menyisakan 16 program yang diproduksi sendiri dengan bantuan sponsor, yang sewaktu-waktu dapat dihentikan produksinya jika sponsor menarik diri.

Kekuatan ekstramedia dijelaskan Shoemaker dan Reese (1996) sebagai faktorfaktor eksternal yang mempengaruhi isi media. Faktor-faktor tersebut adalah: sumber informasi media (misalnya kelompok masyarakat, kampanye humas, kantor berita); sumber pendapatan (pengiklan, pemirsa), institusi sosial lain seperti institusi bisnis dan pemerintahan; lingkungan ekonomi; dan teknologi. Sumber informasi media antara lain adalah sumber berita. Jurnalis tidak dapat menceritakan apa yang tidak mereka ketahui dan mereka yang memiliki kekuatan ekonomi dan politik cenderung mampu mempengaruhi berita (Shoemaker dan Reese, 1996). Sumber-sumber resmi, seperti pegawai pemerintah atau polisi, seringkali lebih dipilih wartawan. Sumber resmi demikian selain mudah diwawancara juga karena wartawan dan editor memiliki persepsi mereka memiliki hal-hal penting untuk disampaikan (Paletz dan Entman, 1981 dalam Shoemaker dan Reese, 1996).

TVRI memiliki sejarah yang dekat dengan pemerintah bahkan menjadi Ideological state apparatus yang menyampaikan kepentingan hegemoni pemerintah. Kini dengan statusnya sebagai LPP, maka TVRI semestinya menjadi media yang mampu memberikan warna lain di industri penyiaran, warna pemberitaan yang mengarah pada kepentingan publik. Namun sejarah dan kondisi TVRI yang dekat dengan pemerintahan dapat menjadi penghambat terjadinya transisi dari televisi propagandis menuju televisi publik. Faktor ideologi yang tertanam dan dianut para staf pemberitaan turut mempengaruhi pemberitaan. Jika ideologi yang ada masih pada ideologi lama, maka dapat menjelaskan mengapa pemberitaan TVRI masih menonjolkan peristiwa dari versi pemerintah dan menonjolkan pencapaian dan keberhasilan pemerintah. Jika ditarik benang merahnya, faktor individu wartawan, rutinitas media, organisasi, pihak eksternal dan ideologi pada TVRI berpautan dengan aspek sejarah dan legal yuridis sehingga menjadikan TVRI belum sepenuhnya memberitakan peristiwa-peristiwa dari sudut pandang yang netral tanpa memihak atau menonjolkan versi pemerintah secara dominan. 
Sedangkan untuk melihat faktor-faktor yang mempengaruhi pemberitaan JTV, peneliti menganalisanya melalui tiga aspek: sejarah, legal-yuridis dan sosiologi media. Secara historis, JTV didirikan oleh media cetak yang didirikan swasta sejak semula, yaitu Jawa Pos. Jawa Pos didirikan warga Surabaya The Chung Sen yang kemudian diambil alih PT Grafiti Pers, juga perusahaan yang didirikan oleh swasta. Lebih lanjut, pada perkembangan setelah era The Chung Sen, Jawa Pos dibesarkan oleh orang-orang dalam media yang terkenal kritis terhadap pemerintahan, majalah Tempo. 'Nahkoda kapal' Jawa Pos selanjutnya juga mantan wartawan Tempo yang kemudian menjadi kepala biro Tempo Surabaya, Dahlan Iskan. Di bawah bimbingan manajemen Eric Samola, Dahlan Iskan membesarkan Jawa Pos. Nampaknya geliat strategi Samola turut mempengaruhi nilai-nilai Dahlan Iskan saat mengembangkan Jawa Pos, sampai ia menyamakan Samola sebagai "bapak"nya.

Secara legal-yuridis, JTV merupakan lembaga penyiaran swasta lokal menurut Undang Undang Nomor 32 tahun 2002 tentang Penyiaran. LPS menurut UU Penyiaran didefinisikan sebagai: Lembaga penyiaran yang bersifat komersial, berbentuk badan hukum Indonesia, yang bidang usahanya hanya menyelenggarakan jasa penyiaran radio atau televisi. Pemusatan kepemilikan dan penguasaan LPS oleh satu orang atau satu badan hukum, baik di satu wilayah siaran maupun di beberapa wilayah siaran, dibatasi. Demikian pula, kepemilikan silang: antara LPS yang menyelenggarakan jasa siar radio dan televisi, antara LPS dan perusahaan media cetak, dan LPS lainnya, baik langsung maupun tidak langsung, dibatasi (pasal 18). Pengaturan tentang jumlah dan cakupan wilayah siaran ditentukan KPI dengan pemerintah.

Bunyi UU Penyiaran memperlihatkan perhatian penyusun perundangan terhadap efek kapital terhadap media penyiaran swasta. Pengaruh globalisasi dan meluasnya televisi berjaringan secara internasional dikhawatirkan membawa ekses kepada media di Indonesia, sehingga kepemilikan asing dibatasi. Pembatasan juga terjadi pada segi program, di mana LPS dibatasi hanya merupakan siaran radio dan televisi, dengan satu siaran-saluran-dan wilayah pada satu waktu. Pembatasan demikian menunjukkan asumsi tak tertulis bahwa dorongan kapital akan mampu membuat LPS merambah ke berbagai sisi jika tidak dibatasi. Pada satu sisi, peraturan demikian membatasi LPS, mengharuskan LPS mengupayakan biaya operasionalnya dari keringat sendiri. Namun di sisi lain, peraturan demikian membebaskan LPS dari kemungkinan pembiayaan pemerintah. Kebebasan dari pendanaan pemerintah menjamin keleluasaan lebih lagi kepada LPS untuk menjadi lembaga penyiaran independen, dibandingkan lembaga penyiaran yang mendapat subsidi tetap dari pemerintah. Faktor legal yuridis inilah yang menurut peneliti turut mempengaruhi bentuk pemberitaan JTV yang secara eksplisit mengkritik pemerintah dalam hal kunker ke Belanda.

Secara sosiologis media, JTV dipengaruhi individu wartawan dan organisasi media. Yang dimaksud individu wartawan adalah latar belakang, sikap, pendidikan, dan sebagainya yang terinternalisasi dalam diri si wartawan. Ada dua persepsi mengenai sikap wartawan terhadap peristiwa. Pandangan pertama adalah yang mengatakan pers hanya dapat menjadi pagar pengaman jika pers sendiri bersikap netral dan imparsial. Sikap netral adalah bagian dari kode etik yang menjamin wartawan tidak memasukkan favoritisme atau pemihakan (partisanship) berdasar ideologi pribadi dalam karyanya. Broder (1992) mengatakan, pelanggaran terhadap kode etik netralitas ini dapat menghancurkan reputasi wartawan, jika ia menganggap 
pendapatnya lebih berharga dari pendapat orang lain. Pandangan ini menganggap hal demikian sebagai arogansi wartawan. Arogansi wartawan, dapat didasarkan oleh kedahsyatan media maupun karakter pribadi wartawan bersangkutan (Ecip, 2000).

Kedahsyatan media diartikan peneliti, wartawan menyadari, setelah masuk menjadi bagian dari institusi media yang besar, ia bukan lagi seseorang, melainkan bagian dari media besar tersebut. Ia menyadari medianya mampu menyampaikan pesan yang akan ditulisnya kepada sejumlah besar massa, memiliki kekuatan untuk menundukkan hanya dengan kekuatan pesan. Pembuat iklan terkemuka dan penulis buku, Jim Aitchison (2004, p. 1) menuliskannya demikian: "The written word is the deepest dagger you can drive into a man's soul" (Kalimat tertulis adalah pisau paling tajam [panjang] yang dapat dihujamkan ke dalam jiwa seseorang). Bersenjatakan media, wartawan dapat lepas kendali ke arah yang negatif. Karena itulah, netralitas yang disertai tanggungjawab bagi sebagian insan pers dianggap syarat wajib yang patut dicapai demi penegakan demokrasi dan keseimbangan-kebebasan berpendapat.

Mengenai pemberitaan kunker Komisi A DPRD Jatim ke Belanda, wartawan JTV tampaknya memiliki cara pandang skeptis, cenderung negatif terhadap kunker dewan. Sikap skeptis cenderung negatif ini membuat wartawan memandang peristiwa penemuan bukti hari jadi Jatim sebagai pendukung persepsi negatifnya terhadap kunker. Sikap ini menjadi salah satu penyebab bagaimana peristiwa penemuan hari jadi Jatim oleh sejarawan Surabaya dapat dikaitkan dengan kesiasiaan kunker Komisi A ke Belanda.

Thomas Griffith pada kolom Newswatch majalah Time tahun 1982 menyebut sikap skeptis jurnalis terhadap pemerintah sebagai "kecondongan yang disebut sinisisme" (Griffith, 1982 dalam Broder, 1992, p. 385) Sinisisme ini, dikatakan menulari banyak aspek jurnalisme di mana wartawan memperlakukan semua isu dan argumen dengan "rasa skeptis yang mendekati muak." Sedangkan Herbert J. Gans menyebut sinisisme ini sebagai ideologi reformis, ideologi yang menuntut adanya perubahan dalam segala bidang. Pandangan reformis inilah yang menurut Gans menyebabkan pers selalu curiga terhadap kecurangan politis, pengaruh uang, dan apa yang dapat dilakukan uang untuk melegalisir kapitalisme. Sikap ini disebut sebagai alasan mengapa wartawan dan pers pada umumnya, tampak selalu melawan pemerintah. Namun wartawan bukan makhluk tanpa pertimbangan yang berkeliling untuk melahap setiap lawannya: pemerintah, hanya karena cara pandang yang ada di benaknya semata-mata.

Meringkas pendapat terdahulu, media cetak memiliki rutinitas yang berbeda dengan televisi. Namun jika warna berita yang diusung serupa, diduga ada pengaruh organisasi yang berperan di dalamnya. Pengaruh organisasi ini selain mempengaruhi bentuk produk berita, turut pula mempengaruhi individu-individu di dalamnya. Bordeau (1977 dalam Badriati, 2006) menyebut istilah lingkungan demikian sebagai habitus. Habitus, menurut Bordeau adalah kecenderungan tetap yang menjadi kebiasaan, mendorong praktik berulang sehingga terbentuk menjadi struktur. Habitus tidak beku dan permanen, melainkan bertahan lama dan dapat berubah (Badriati, 2006). Habitus adalah produk internalisasi struktur yang mampu menstrukturkan kehidupan sosial di mana kehadiran dan cara kerjanya seringkali tidak disadari namun mewujud dalam kegiatan praktis individu (Badriati, 2006). Jadi, pandangan negatif terhadap pemerintah ini dapat hadir tanpa disadari sepenuhnya oleh wartawan, karena pembenaran diri bahwa pers harus menjadi anjing penjaga 
telah lama termaktub dalam rutinitas organisasi. Habitus mempengaruhi cara pikir dan tindakan wartawan, berdialektika menjadi semacam struktur tak tertulis.

Faktor-faktor yang memengaruhi berita dalam organisasi dapat diringkas menjadi tiga: kepemilikan, tujuan, dan kebijakan. Dari segi kepemilikan, seperti telah disebut dalam aspek historis, JTV dimiliki swasta sejak dari mula, bernaung di bawah manajemen PT Jawa Media Televisi yang 100 persen sahamnya dimiliki PT Jawa Pos Group (Sudibyo, 2004). Faktor kepemilikan yang tidak berkaitan dengan lembaga pemerintah secara teoretis akan menyebabkan wartawan memiliki keleluasaan lebih besar dari organisasinya untuk mengkritik pemerintah. Tahun 2000 Jawa Pos menerima penghargaan Best Customer Satisfaction dari majalah Frontier dan SWA. Pengakuan dan kekuatan secara finansial, merupakan salah satu syarat independensi media. Independensi media, menjadi syarat untuk mampu melakukan perlawanan terhadap penguasa, sekalipun ada represi. Jadi, faktor kepemilikan -dan secara tidak langsung, finansial-- berpengaruh terhadap pemberitaan JTV.

Dari segi tujuan, dapat diketahui JTV memiliki tiga tujuan yang mendasari pendiriannya: 1) menjadi medium komunikasi antara pemerintah, masyarakat, dan pengusaha. 2) mengupayakan demokrasi dan menjadi ajang aktivitas bersama warga Jawa Timur, dan 3) menjadi media yang independen, obyektif, jujur, dan berpartisipasi dalam pemberdayaan masyarakat. Faktor tujuan ini menguatkan argumen independensi dan demokrasi yang berfokus pada rakyat, yang dimampukan kepemilikan JTV. Sedangkan dari faktor kebijakan, slogan lokal, nakal, dan massal menggambarkan kebijakan program JTV. Faktor organisasi yang mendukung independensi media ini secara teoretis dapat dianggap sebagai salah satu faktor mengapa berita JTV dalam hal kunker Komisi A DPRD Jatim menonjolkan ketidakberesan pemerintah.

Kekuatan ekstramedia yang menurut peneliti turut mempengaruhi pemberitaan JTV mengenai hari jadi Jatim antara lain sumber informasi media dan sumber pendapatan. Faktor institusi bisnis dan pemerintahan, lingkungan ekonomi, dan teknologi tidak tampak berpengaruh. Sumber informasi media di sini adalah narasumber. JTV menggunakan satu narasumber, sejarawan Surabaya Oerip Soedarman. Penggunaan satu narasumber menyebabkan wartawan mendapat detil sejarah dan keterangan sepihak. Efeknya, wartawan menganggap pemaparan narasumbernya satu-satunya kebenaran. Anggapan ini mengakibatkan bingkai berpikir mendelegitimasi pemerintah, yang nampak pada narasi berita wartawan.

\section{KESIMPULAN}

Peneliti mendapati, TVRI dalam struktur sintaksis memberi kesan berita tidak penting dengan tidak menampilkan berita sebagai berita utama. TVRI menonjolkan pendapat dan penokohan narasumber pihak pemerintah, mengulas peristiwa dari sudut pandang pemerintah didukung detil. Sementara, JTV memberi kesan berita penting, menampilkan berita sebagai berita utama. JTV menonjolkan temuan narasumber non pemerintah untuk memperbandingkan dengan hasil pemerintah, mengulas peristiwa dari sudut pandang wartawan didukung detil.

Sementara pada struktur skrip, TVRI memaparkan kontroversi di awal namun kemudian menonjolkan sudut pandang pemerintah. TVRI terkesan hendak memaparkan pro dan kontra namun pada keseluruhan memaparkan temuan tanggal 
pemerintah sehingga terkesan cenderung memihak versi pemerintah. JTV memperlawankan narasumbernya dengan Komisi A. JTV mendukung sudut pandang wartawan menggunakan kutipan sumber dan detil legal sejarah.

Pada struktur tematik, TVRI menggunakan tema dan detil legal yuridis historis untuk mendukung kesan: pemerintah -bagian dari pemirsa- bertindak aktif menemukan hari jadi Jatim. JTV sebaliknya, menggunakan tema dan detil untuk menonjolkan keabsahan temuan Soedarman, menunjukkan kunker sia-sia.

Struktur retoris TVRI menonjolkan keaktifan, keberhasilan pembangunan, dan persamaan visi pemerintah-pemirsa menggunakan unsur wacana: klaim, pilihan kata, gambar, dan retorika. TVRI mendukung profil pemerintah, menenggelamkan kontroversi seputar penyelenggaraan hari jadi Jatim. JTV menggunakan unsur wacana untuk menonjolkan profil dan keberhasilan narasumbernya. Unsur wacana digunakan JTV untuk mendelegitimasi kunker. Keseluruhan struktur bingkai dalam berita kunker menunjukkan sikap TVRI cenderung pada pemerintah dan JTV mengkritik pemerintah.

Perbedaan bingkai ini dapat dijelaskan melalui pendekatan historis, legalyuridis, dan sosiologi. Secara historis, legal-yuridis, TVRI memiliki kedekatan dengan pemerintah, selama bertahun-tahun telah digunakan sebagai alat hegemoni dan propaganda. Faktor sejarah dan legal mengindikasikan peran aktif pemerintah baik secara pendanaan maupun ideologi dalam diri TVRI masih cukup besar, dan hal ini menghambat TVRI untuk memberitakan ketidakberesan dalam diri pemerintah secara lugas dan berani. Sementara, sejarah historis dan legal-yuridis juga berpengaruh terhadap JTV. JTV secara historis tidak memiliki kedekatan dengan pemerintah juga secara legal-yuridis tidak tergantung pemerintah. Kondisi ini turut mempengaruhi secara sosiologis sehingga ketidakberesan pemerintah dapat diberitakan dengan lebih lugas, berani dan bahkan opinionatif.

Secara sosiologis, individu, rutinitas organisasi, organisasi (peran pemilik, tujuan, dan kebijakan media), kekuatan ekstramedia, dan ideologi mempengaruhi TVRI sehingga cenderung menonjolkan peristiwa dari sisi pemerintah. Individu, rutinitas, dan organisasi TVRI masih terpengaruh bentukan Orde Baru sehingga melihat kejadian dari sudut pandang pemerintah. Faktor kekuatan ekstramedia dan ideologi pemerintah masih berperan sehingga menjadi faktor tambahan pemberitaan TVRI condong kepada pemerintah.

Faktor individu wartawan, organisasi, kekuatan ekstramedia (pengiklan dan pemirsa), dan ideologi mempengaruhi JTV sehingga pemberitaannya satu sisi, mendelegitimasi pemerintah, menonjolkan kesahihan temuan hari jadi sejarawan. Sejarah JTV sebagai media swasta mempengaruhi individu wartawan, rutinitas organisasi, dan organisasi medianya, mengkritik pemerintah secara lebih lugas. Bentuk JTV sebagai media swasta menempatkan pengiklan dan pemirsa sebagai faktor yang berpengaruh, sehingga JTV membuat berita satu sisi, tajam, supaya mudah dicerna pemirsanya. Secara ideologi, kapitalisme secara teoretis menjadi ideologi JTV, namun ideologi ini nampaknya tidak langsung mempengaruhi pemberitaan JTV terkait kunker dewan. Kapitalisme JTV lebih ke arah pemberitaan yang mudah dicerna, dan hubungan baik yang dibina dengan narasumber. Namun demikian bentuk berita satu sisi, pilihan kata tajam, mampu menarik pemirsa dan pemasang iklan. 


\section{DAFTAR PUSTAKA}

Aitchison, Jim. (2004). Cutting edge advertising: How to create the world's best print for brands in the $21^{\text {st }}$ century. Singapore: Pearson Education

Aka, Surya. (2008, May 27). Wawancara pribadi.

Ali, Novel. (1998). Pers objektif, media pemberdayaan masyarakat yang efektif. Jurnal Ikatan Sarjana Komunikasi Indonesia, 1/Juli 1998.13-23.

Althusser, Louis. (2004). Tentang ideologi: marxisme strukturalis, psikoanalisis, cultural studies. Yogyakarta: Jalasutra.

Berger, Peter L. \& Luckmann, Thomas. (1966) The social construction of reality. New York: Anchor Books. April 17, 2008 http://www.brainwashed.com/h3o/ Dislocation/ reality.html

Berger, Peter L. \& Luckmann, Thomas. (1990) Tafsir sosial atas kenyataan: Risalah tentang sosiologi pengetahuan. Jakarta: LP3ES

Bungin, Burhan. (2001). Metodologi penelitian sosial: format-format kuantitatif dan kualitatif. Surabaya: Airlangga University Press

Burton, Graeme. (2007). Membincangkan televisi: sebuah pengantar kepada kajian televisi. Yogyakarta: Jalasutra

Chandler, Daniel. (1994). Grammar of television. April 17, 2008. http://www.aber.ac.uk/media/Documents/short/gramtv.html

Colman, Andrew M. (2001). A Dictionary of Psychology. April 17, 2008. http://www.encyclopaedia.com/doc/1087-constructivism.html

Djuraid, Dhimam Abror. (2007). Globalisasi, modernisasi, hibridisasi: catatan mingguan seorang wartawan. Surabaya: Pustaka Eureka

Ecip, S. Sinansari. (2000). Dinamika keterbukaan, kebebasan, dan tanggungjawab media komunikasi massa di Indonesia. Jurnal Ikatan Sarjana Komunikasi Indonesia no.5/ Oktober 2000

Elson, Robert E. (2000). Mencari Soeharto. Kristanto, JB (ed.) (2000). Seribu Tahun Nusantara. Jakarta: Penerbit Buku Kompas

Endarmoko, Eko. (2006). Tesaurus bahasa Indonesia. Jakarta: Gramedia Pustaka Utama

Eriyanto. (2001). Analisis wacana: pengantar analisis teks media. Yogyakarta: LKiS

Eriyanto. (2002). Analisis framing: konstruksi, ideologi, dan politik media. Yogya: $L K i S$

Fiske, John. (2005). Cultural and communication studies: sebuah pengantar paling komprehensif. Yogyakarta: Jalasutra

Flick, Uwe (1998) An introduction to qualitative research. London: SAGE 
Ghazali, Effendy, dkk.. (2003). Konstruksi sosial industri penyiaran (plus acuan tentang penyiaran publik dan komunitas). Jakarta: Departemen Ilmu Komunikasi FISIP UI

Hardiman, F. Budi. (2003). Melampaui positivisme dan modernitas: Diskursus filosofis tentang metode ilmiah dan problem modernitas. Yogyakarta: Kanisius

Haryanto, Ignatius. (tanpa tahun). Capital, regulation, and 'new freedom': The media conglomerates and broadcasting law in the post Authoritarian regime in Indonesia. April 21, 2008. http://www.bogor.net/idkf/idkf/aplikasi/mediaonline/Paper\%20Curtin.doc

Hurek, Lambertus L. (2007). Ambruknya TVRI Jatim. March 23, 2007 http:/hurek.blogspot.com/2007/03/ambruknya-tvri-surabaya-jatim.html

Institut Studi Arus Informasi. (1998). Kami ingin presiden baru. Polling Tempo Interaktif. (Tanpa lokasi): ISAI

Jawa Pos Media, PT.. (2003). Company profile: Entrepreneur of the year. Jawa Pos Online. April 22, 2008. http://www.indopos.co.id/cv/10_english.htm

Jawa Pos Media, PT. (2007). Company profile: Semuanya berawal dari 1949.... Jawa Pos Online. April 22, 2008. http://www.indopos.co.id/cv/02_indonesia.htm

Jawa Media Televisi, PT.. (2006). Company profile. April 22, 2008. http://www.jtv.co.id/companyprofil.php

Komisi D tunda ke Belanda: Buntut kontroversi kunker Komisi A. (2007, 30 Juli). Jawa Pos. p. 29

Karim, Niniek L. dan Takwin, Bagus. (May 5, 2000). Analisis Psikologis terhadap Kepribadian Soeharto.. April 17, 2008. http://www.mailarchive.com/permias@listserv.syr.edu/msg11004.html

Kitley, Philip. (2000). Konstruksi budaya bangsa di layar kaca. Jakarta: Media Lintas Inti Nusantara

Komisi Pemberantasan Korupsi. (2005) Laporan Dugaan Korupsi Peralatan Siaran di Televisi Republik Indonesia (TVRI). April 18, 2008. http://www.antikorupsi.org/docs/tvrikpk.pdf.

Kovach, Bill \& Tom Rosenstiel. (2001). Sembilan elemen jurnalisme. Jakarta: Pantau

Kriyantono, Rachmat. (2006). Teknik praktis riset komunikasi. Jakarta: Kencana Prenada Media Group

Larson, Charles U. (2004) Persuasion: reception and responsibility (10th ed). Illinois: Thomson-Wadsworth

McCombs, Maxwell \& Ghanem, Salma M.. The convergence of agenda setting and framing. In Reese, S. D., Gandy, O. H., Grant, A. E.. (2001). Framing public life: Perspectives on media and our understanding of the social world. USA: Lawrence Erlbaum Associates 
McQuail, Denis. (2000). Mass communication theory, $4^{\text {th }}$ ed. London: SAGE

Merril, John C. \& Lowenstein, Ralph L.. (1979). Media, messages, dan men: new perspective in communication, $2^{\text {nd }} \mathrm{ed}$. NY: Longman

Moleong, Lexy J. (2007). Metode penelitian kualitatif, edisi revisi. Bandung: Remaja Rosdakarya

Morrisan. (2003). Jurnalistik televisi mutakhir. Jakarta: Ghalia Indonesia

Penerbit Sinar Grafika. (2003). Undang-Undang Penyiaran RI No. 32 Th. 2002.

Poerwadarminta, WJS. (1976). Kamus umum bahasa Indonesia. Jakarta: PN Balai Pustaka (diolah kembali oleh Pusat Pembinaan dan Pengembangan Bahasa Depdikbud)

Prita, B. Ardhanari. (2005). Analisis berita headline halaman muka Kompas dan Republika edisi Agustus 2004. Jurnal Ilmiah Communique vol 1/2, Januari 2005. 94-106

Pribadi, Buyung Asmono. (2006). Teknik penulisan naskah berita televisi. Bahan ajar kuliah Teknik Penulisan Naskah Berita Televisi Fakultas Ilmu Komunikasi Universitas Kristen Petra Surabaya

Rumokoy, Joyce. (2008, May 29). Wawancara pribadi.

Sastrosatomo, Soebadio. (1998). Manifes kedaulatan rakyat. Jakarta: Pusat Dokumentasi Politik "Guntur 49"

Severin, Werner J. \& Tankard Jr., James W.. (2001). Communication theories: origins, methods, and uses in the mass media, (5th ed.). Texas: Longman

Sobur, Alex. (2006). Analisis teks media: suatu pengantar untuk analisis wacana, analisis semiotik, dan analisis framing. Bandung: Remaja Rosdakarya

Steele, Janet. (2007). Wars within: pergulatan tempo, majalah berita sejak jaman orde baru. Jakarta: Dian Rakyat

Stovall, James Glen. (2005). Journalism: who, what, when, where, why, and how. Alabama: Pearson Education

Sudibyo, Agus. (2001). Politik media dan pertarungan wacana. Yogyakarta: LKiS

Sudibyo, Agus. (Juni 26, 2003). Nasionalisme dan kebebasan pers. Kompas Cyber Media. April 17, 2008. http://64.203.71.11/kompas-cetak/0306/26/opini/386303. htm

Sudibyo, Agus. (2004). Ekonomi politik media penyiaran. Yogyakarta: LKiS dan ISAI 